\title{
Flood risk trends in coastal watersheds in South Spain: direct and indirect impact of river regulation
}

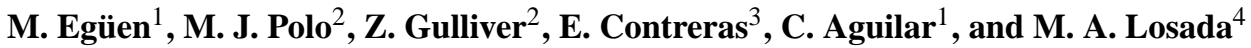 \\ ${ }^{1}$ University of Granada, Fluvial Dynamics and Hydrology - Andalusian Institute of Earth System Research, \\ Granada, Spain \\ ${ }^{2}$ University of Cordoba, Fluvial Dynamics and Hydrology - Andalusian Institute of Earth System Research, \\ Cordoba, Spain \\ ${ }^{3}$ University of Cordoba, Fluvial Dynamics and Hydrology, Cordoba, Spain \\ ${ }^{4}$ University of Granada, Environmental Flux Dynamics - Andalusian Institute of Earth System Research, \\ Granada, Spain \\ Correspondence to: M. Egüen (meguen@ugr.es)
}

Received: 12 March 2015 - Accepted: 12 March 2015 - Published: 11 June 2015

\begin{abstract}
Spain is one of the world's countries with a large number of reservoirs per inhabitant. This intense regulation of the fluvial network during the 20th century has resulted in a decrease in flood events, a higher availability of water resources, and a high development of the irrigated crop area, even in the drier regions. For decades, flood perception was reduced since the development of reservoirs protected the floodplains of river; this resulted in later occupation of soil by urban, agricultural and industrial uses. In recent years, an increasing perception of flood events is observed, associated to the higher damage associated to extreme events in the now occupied areas, especially in coastal watersheds. This work shows the change on flood risk in the coastal areas of three hydrographic basins in Andalusia (South Spain) during the reservoir expansion period: the Guadalete, Guadalquivir and Guadalhorce river basins. The results differentiate the impact of the regulation level on both the cumulative distribution functions of the fluvial discharge near the river mouth, for different time scales, and the associated damage related to the enhanced soil occupation during this period. The different impact on the final medium and long term flood risk is also assessed in terms of the storage capacity per unit area throughout the basins, the effective annual runoff/precipitation index, the frequency of sea storms, and the human factor (change in social perception of floods), for different intervals in the flood extreme regime. The implications for adaptation actions is also assessed.
\end{abstract}

\section{Introduction}

The natural river flow regime determined by atmospheric factors is nowadays very modified by anthropogenic factors in much of the world. In recent decades storage systems thorughout the basins have been developed by building reservoirs. These allow to collect water during wet periods and to release it during dry periods (Efstratiadis et al., 2013). The evolution of the reservoir network has gone hand in hand with the expansion and intensification of agriculture due to the development of irrigation technology, and with the development of urban and industrial areas that have occupied flood plains and tidal flood plain. Thus, given the growing demand for water, the reservoirs manage water resources in those areas with no temporal coincidence of periods of increased demand and higher water availability throughout the year. The implications of this development have been widely studied in different parts of the world. In this way, Maheshwari et al. (1995), Magilligan and Nislow (2005), Frazier and Page (2006), and Wang et al. (2006) described how dams alter the natural regime by reducing peak flows and rising lows flows with seasonal redistribution, and how the magnitude of average annual floods are reduced. This has direct effects on ecosystems downstream from dams (García de Jalón, 2003; 


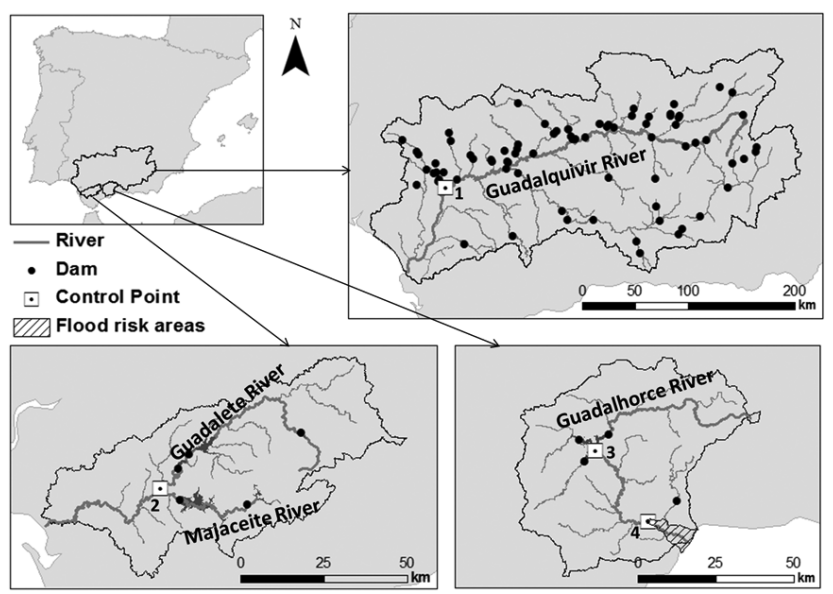

Figure 1. Location of the Guadalquivir, Guadalete and Guadalhorce rivers basins and location of the dams and control points.

Baeza Sanz et al., 2005) and in water quality depending on the uses satisfied. In addition, in the new occupied areas there may be flood events that are exacerbated in coastal areas in a context of rising sea levels associated with the current period of global warming and the possible increase in torrential precipitation events inland and storms on the coast.

These facts are especially remarkable in systems where the temporal variability of precipitation and thus the associated variable flows plays an important role. This is the case of Andalusian basins (southern Spain) that are subject to a Mediterranean climate with high seasonal and inter-annual variability (Lorenzo-Lacruz et al., 2011). Also, the spatial variability in the distribution of precipitation must be added to the temporal variability. This variability becomes even more relevant when the size of the basin increases, due on one hand to the topography itself and secondly, to the origin and characteristics of the storms that originate precipitation throughout the basin (Egüen, 2014).

This study shows the change in the perception of the risk of flooding related to the evolution of the storage capacity in coastal areas of three watersheds in Andalusia: the Guadalquivir, Guadalete and Guadalhorce river basins. They have different characteristics in terms of size, rainfall and storage capacity. However, all these basins suffer recurrent floods since ancient times, specially in the estuary area and surrounding upstream areas, where damages are exacerbated by the gradual occupation of the main channel floodplains.

\section{Study Area and data availability}

The three studied basins are located in Andalusia (Fig. 1). They are affected by the high seasonality in the precipitation regime with frequent torrential rainfalls, typical of the Mediterranean climate. Therefore, the natural flow regime also shows a seasonal pattern. Agriculture is main land use in
Table 1. Geomorphological and climatic characteristics of the Guadalquivir, Guadalete and Guadalhorce basins.

\begin{tabular}{lrrr}
\hline & Guadalquivir & Guadalete & Guadalhorce \\
\hline Basin area & $57000 \mathrm{~km}^{2}$ & $3677 \mathrm{~km}^{2}$ & $3157 \mathrm{~km}^{2}$ \\
River length & $657 \mathrm{~km}$ & $157 \mathrm{~km}$ & $154 \mathrm{~km}$ \\
Basin elevation & $3480 \mathrm{~m}$ & $1641 \mathrm{~m}$ & $1800 \mathrm{~m}$ \\
Annual mean temperature & $16.8^{\circ} \mathrm{C}$ & $17.8^{\circ} \mathrm{C}$ & $17.3^{\circ} \mathrm{C}$ \\
Annual mean precipitation & $450 \mathrm{~mm}$ & $645 \mathrm{~mm}$ & $546 \mathrm{~mm}$ \\
Number of reservoirs & 57 & 5 & 4 \\
Storage capacity & $8800 \mathrm{hm}^{3}$ & $1373 \mathrm{hm}^{3}$ & $369 \mathrm{hm}^{3}$ \\
Storage capacity/unit area & 0.15 & 0.37 & 0.12 \\
\hline
\end{tabular}

the basins. Table 1 summarizes the main geomorphological and climatic characteristics of the study sites.

The basin of the Guadalquivir River on the Atlantic coast, is the largest in Andalusia and one of the largest in Spain, with $57000 \mathrm{~km}^{2}$. The rainfall pattern is influenced by storms of different origin, Atlantic or Mediterranean, depending on the area of the basin. Its hydrological system is highly regulated with 57 dams. Alcalá del Río reservoir (point1 in Fig. 1), built in 1931 and located in the main stream, is the closest reservoir to the estuary.

The Guadalete River Basin, also on the Atlantic side, is fiveteen times smaller than the Guadalquivir basin. With only five dams, it has higher level of regulation per unit area than Guadalquivir (Table 1). The dams are located along two main channels (Fig. 1). The Guadalete and the Majaceite Rivers. The presence of gauging stations in the headwater subbasins that measure the natural flow regime facilitates the study of rainfall-runoff relationships.

Finally, the Guadalhorce River Basin, in the Andalusian Mediterranean area, has an area similar to Guadalete River Basin. Here, the occurrence of cold drop flash-floods are frequent due to torrencial rainfall events and the low travel time of the flow along the basin. This phenomena regularly affects urban areas and communication routes that occupy floodplains along the river network causing heavy economic and human damages especially in the area near the mouth (Gulliver et al., 2014; Herrero et al., 2014). There are four reservoirs (Fig. 1). The first three of them) belong to the Guadalhorce Reservoir System and are located next to each other. The three of them release water flows in a short distance (point 3 in Fig. 1). These reservoirs are meant to guarantee downstream supply for crop irrigation, to reduce the risk of flooding, to increase energy production and for recreational uses, in order to priority. Finally the remaining reservoir was built to control river flooding in the plains and to improve the urban water supply. The storage capacity in this basin is similar to the Guadalquivir basin.

Daily flow data $\left(\mathrm{m}^{3} \mathrm{~s}^{-1}\right)$ used in this study were provided by the Automatic Hydrological Information System (SAIH) of the Guadalquivir - Guadalete and Barbate rivers. Hourly flow data $\left(\mathrm{m}^{3} \mathrm{~s}^{-1}\right)$ and water level data $(\mathrm{m})$ at a gauge station in Guadalhorce basin (point 3 in Fig. 1) by SAIH of 
Table 2. Storage capacity of the contributing area to the estuary of Guadalquivir accumulated at the end of each period. Mean daily flow distribution in Alcalá del Río reservoir for selected percentiles during the four periods associated with increasing regulation levels in the upstream basin. In the last column, flow reduction values with respect to the initial period value.

\begin{tabular}{|c|c|c|c|c|c|c|}
\hline & & 1930-1937 & $1937-1969$ & 1969-1990 & 1990-2010 & \\
\hline $\begin{array}{l}\text { Accumulated storage capacity } \\
\left(\mathrm{hm}^{3}\right)(\% \text { actual value })\end{array}$ & $500(6 \%)$ & $4500(50 \%)$ & $6400(75 \%)$ & $8800(100 \%)$ & & $\begin{array}{r}\text { Flow } \\
\text { reduction }(\%)\end{array}$ \\
\hline \multirow[t]{6}{*}{$Q\left(\mathrm{~m}^{3} \mathrm{~s}^{-1}\right)$} & Percentil 99 & 2800 & 2159 & 1017 & 1440 & $-48.6 \%$ \\
\hline & Percentil 90 & 548 & 378 & 161 & 104 & $-81.0 \%$ \\
\hline & Percentil 50 & 67 & 56 & 34 & 23 & $-65.7 \%$ \\
\hline & Percentil 25 & 28 & 30 & 21 & 10 & $-64.3 \%$ \\
\hline & Maximum & 5300 & 5700 & 3200 & 3670 & $-30.7 \%$ \\
\hline & Mean & 232 & 172 & 85 & 76 & $-67.2 \%$ \\
\hline$\%$ floods & & $62 \%$ & $54 \%$ & $33 \%$ & $19 \%$ & \\
\hline
\end{tabular}

Table 3. Statistical values of daily mean observed flow for the final stretch of Guadalete River, on the confluence of the two main channels. 1-4 are period with different storage capacity: $1000 \mathrm{hm}^{3}(73 \%), 1135 \mathrm{hm}^{3}(83 \%), 1149 \mathrm{hm}^{3}(84 \%)$ and $1372 \mathrm{hm}^{3}(100 \%)$, corresponding to 1959-1967, 1967-1970, 1970-1991, 1991-2014. Modified flow reduction from the natural scenario is shown (negative sign: reduction, positive sign: increase).

\begin{tabular}{|c|c|c|c|c|c|c|c|c|c|}
\hline & \multicolumn{4}{|c|}{ Observed flow $\left(\mathrm{m}^{3} \mathrm{~s}^{-1}\right)$} & \multirow{2}{*}{$\begin{array}{c}\text { Observed flow reduction }(\%) \\
(\text { Period 4-Period } 1)\end{array}$} & \multicolumn{4}{|c|}{ Observed-natural flow reduction (\%) } \\
\hline & 1 & 2 & 3 & 4 & & 1 & 2 & 3 & 4 \\
\hline Percentil 99 & 192.76 & 191.97 & 52.25 & 69.89 & -63.74 & -25.55 & -45.35 & -60.11 & -68.36 \\
\hline Percentil 95 & 72.57 & 51.64 & 19.57 & 15.36 & -78.83 & -29.76 & -16.57 & -47.92 & -69.92 \\
\hline Percentil 90 & 35.79 & 32.67 & 14.81 & 11.5 & -67.87 & -28.66 & -0.11 & -16.8 & -44.19 \\
\hline Percentil 75 & 19.69 & 16.75 & 8.33 & 8.13 & -58.71 & 18.76 & 55.4 & 58.06 & 78.98 \\
\hline Percentil 50 & 12.7 & 10.89 & 4.27 & 3.04 & -76.06 & 138.98 & 183.62 & 247.31 & 303.51 \\
\hline Percentil 25 & 5.25 & 5.17 & 0.55 & 1.03 & -80.38 & 148.83 & 501.12 & - & - \\
\hline Percentil 10 & 1.88 & 2.62 & 0.21 & 0.38 & -79.79 & 234.52 & 611.48 & - & - \\
\hline Maximun & 1348.30 & 607.00 & 282.44 & 361.88 & -73.16 & 0.00 & -30.06 & -43.25 & 62.74 \\
\hline Mean & 20.79 & 19.04 & 6.55 & 6.49 & -68.78 & -5.06 & 9.78 & -23.17 & 42.29 \\
\hline
\end{tabular}

the Andalusian Mediterraneam Basin were available at the Guadalhorce basin.

Land use data were obtained from the Map of Uses and Land Cover in Andalusia (Consejería de Medio Ambiente, 2010). This map has information about the area occupied by agricultural, forestry/natural, built and surface water uses in the basin, in several years: 1956, 1977, 1984, 1999, 2003 and 2007.

In Guadalhorce case, daily rainfall data of 6 meteorological stations from the Meteorology State Agency (AEMET) were available to identify heavy rainfall events.

\section{Methods}

\subsection{Effect of regulation on the flow regime}

Firstly, the evolution of storage capacity in the basin is analyzed over time. Storage capacity is defined as the volume of reservoirs. This study was carried out in the basins of the Guadalquivir and Guadalete, where a complete series of av- erage daily discharge to the estuary is available in the study sites.

Secondly, different periods of time depending on the level of regulation were established and the cumulative distribution functions (CDF) of inflows to each estuary were analyzed for each period. In the case of the Guadalquivir, discharges were analyzed from the Alcalá del Río reservoir (point 1 in Fig. 1), with available data from 1931. In the case of Guadalete the study point is the confluence of the two main channels, located a few kilometers upstream of the estuary (point 2 in Fig. 1). The sum of the discharge of the two reservoirs located near this intersection, is assumed to approximate the inflow to the estuary of the Guadalete River (Egüen, 2014), with available data from 1959.

Finally, a comparison of the measured flow rate with the hypothetical natural flow regime was carried out in the Guadalete basin. The natural flow data were restored by balance of water in reservoirs once they were calibrated with simulated natural flows in the area with WiMMed model (Egüen, 2014). 

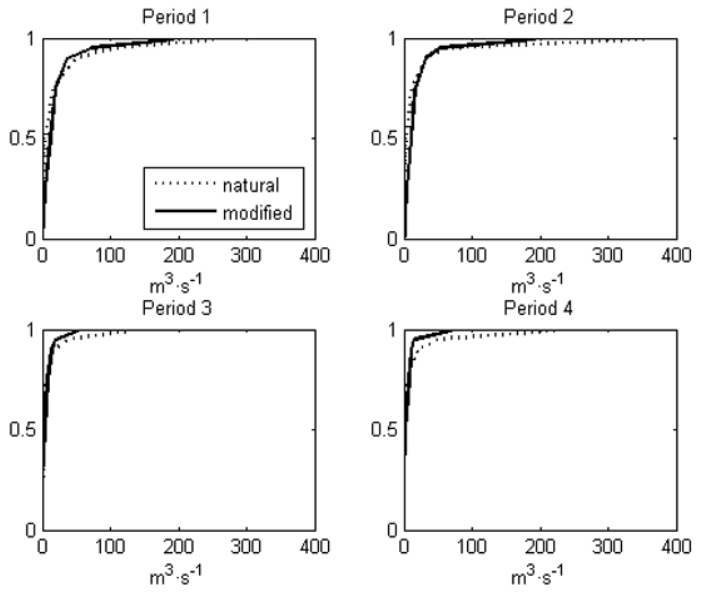

Figure 2. CDF curves of daily natural flow (dot line) and daily modified flow (thick line) for the four periods corresponding to increasing storage levels, in the Guadalete River.

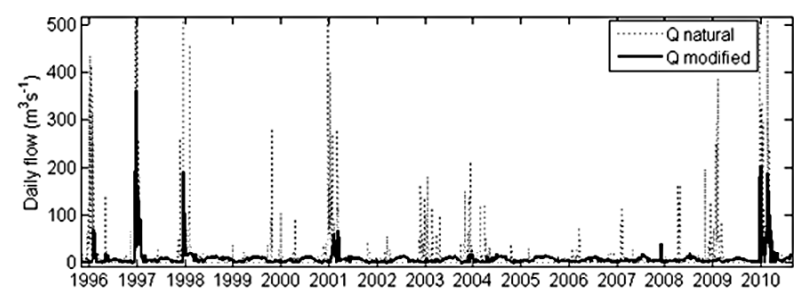

Figure 3. Detail of the period under current regulation level: average daily flow observed (modified regime; thick line) and restored (natural regime; dot line) in the final stretch of the Guadalete River downstream of the confluence of the two main channels.

\subsection{Effect of regulation on land use changes}

Changes in land use were analyzed according to the percentage of change from 1956 to 2007 for each land use. Correlation was analyzed between the irrigated area and storage capacity in the basin, as well as with the change of the flow regime.

\subsection{Effect of regulation on floods}

For the Guadalhorce case, the occurrence of floods was analysed for the period 1996-2014. First, heavy rainfall events were identified as those events with a rainfall higher than $100 \mathrm{~mm}$ in $24 \mathrm{~h}$ (Senciales and Damián, 2013). Then, the occurrence of heavy events was compared to the daily maximum water level measured close to the river mouth (point 4 in Fig. 1).

The threshold for a flood event was established in 3.5 meters according to Regodón (2013), who studied the last two catastrophic flood events (15 February 2010 and 28 September 2012) through hydrological modelling in the basin. Finally, the occurrence of flood events was similarly compared to the daily maximum discharge from the reservoir system

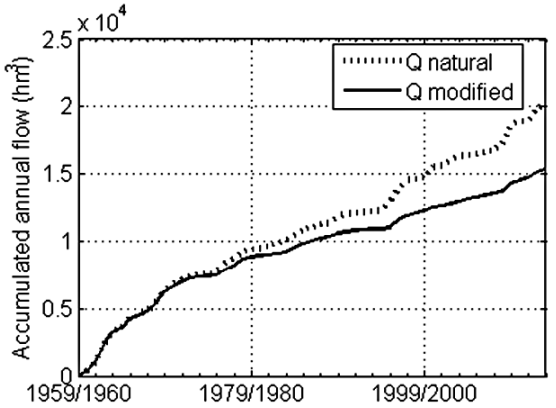

Figure 4. Annual natural regime flow (restored) and annual modified regime flow (measured discharges) (hydrological year from September to August) accumulated throughout the study period in the final stretch of the Guadalete River, downstream the confluence of the two main rivers. a)

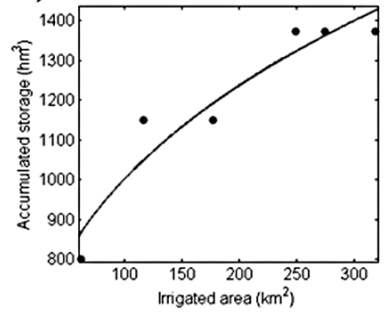

b)

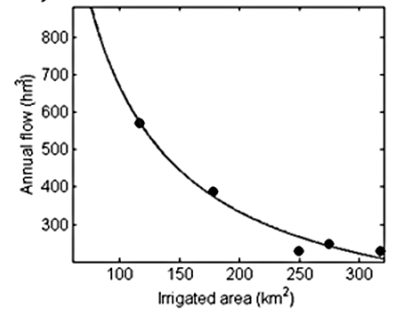

Figure 5. (a) Relation between storage capacity in the basin contributing to Guadalete estuary and irrigated crops area and (b) relation between annual flow discharged to the Guadalete estuary in the last 20 years and irrigated crops area for the period 1956-2007.

(point 3 in Fig. 1), situated in the upstream part of the river course.

\section{Results}

For both the Guadalquivir and the Guadalete river basins the variation of the flow regime supplied from the basin to the estuaries and the evolution of land uses in the basins have been analyzed in terms of the degree of regulation achieved. Finally, in the Guadalhorce, precipitation, water level and discharge of the reservoirs were related for a brief understanding of the latest floods.

\subsection{Effect of regulation on the flow regime}

In the Guadalquivir basin four periods were established from 1930 to 2010 , corresponding to $6,50,75$ and $100 \%$ levels of control over the current level reached in the basin (Table 2). As regulation increases, the level of the average flow becomes smaller, decreasing for the last period by $67 \%$ compared to first one. The CDF of flows for each period shows a decrease in the flow for all percentiles with the greatest re- 
a)

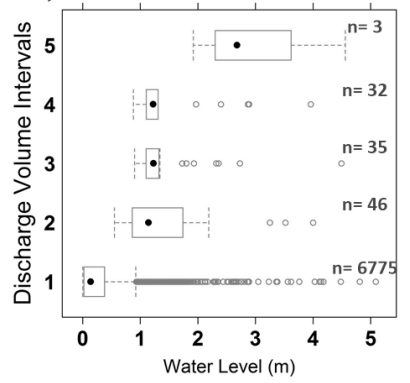

b)

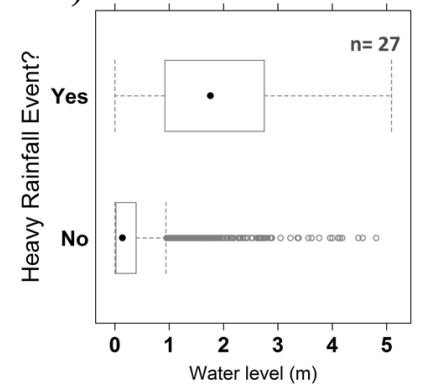

c)

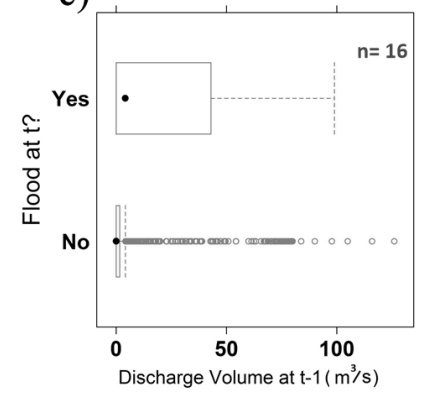

Figure 6. (a) Relation between discharge intervals and the daily maximum water height $(\mathrm{m})$ measured at Cártama. Range intervals $\left(\mathrm{m}^{3} \mathrm{~s}^{-1}\right)$ : $[0,25.2](25.2,50.4](50.4,75.6](75.6,101](101,126]$. (b) Ocurrence of heavy rainfall events related with the water level. (c) Ocurrence of floods related with time-lagged $(t-1)$ discharge values used.

duction for the 90th percentile. Maximum flows decrease to a lesser extent.

For the Guadalete basin, the average rate of discharge into the middle and lower reaches of the basin decreases by $69 \%$ (Table 3). In this case a decrease in all percentiles of the CDF is also observed with higher reductions in the low and mean regime (reduction of 80 and $76 \%$ for the percentiles 25 and 50 ) than during high flows (reduction of $68 \%$ for the 90th percentile). In both basins extreme values are more conditioned by the wet or dry character of the period than by regulation.

On the other hand, percentiles of the observed data and estimated natural regime in the basin of Guadalete have been compared. It is observed that values of 75 th percentil and lower of observed flow are higher than for the estimates in natural regime. For larger percentiles, associated with extreme flows, values are lower, with a greater decrease with increasing regulation (Fig. 2). This indicates that reservoirs reduce extreme flood flows and they are distributed in time as a low flow. Figure 3 shows the comparison of the estimated natural flow and the actual flow rate where the redistribution effect of flow over time by dams can be observed. The total annual flow decreases under the existence of reservoirs due to consumption and due to the increased volume evaporated with the presence of those water surfaces. This reduction becomes greater with increasing regulation (Fig. 4).

\subsection{Effect of regulation on land use changes}

Over the years there have been changes in land use in the study areas. There has been a remarkable intense urbanization and a change of agricultural practices towards irrigated crops at the expense of rainfed ones. As for the Guadalquivir, it is worth noting the increase in urban and residential areas by $350 \%$ in the estuary and $86 \%$ in the basin upstream during the period 1956-2007. The surface devoted to agricultural use generally does not change, however irrigated crops increase during the period by $6 \%$ in the entire basin. This increase is particularly relevant in the area of the estuary.
In the Guadalete, the increase of urban areas and irrigated crops in the period 1956-2007 is 9 and $8 \%$ respectively, decreasing to the same extent the area under rainfed crops, $17 \%$.

In the Guadalhorce there is a significant increase of $14 \%$ in urban areas in the period 1956-2007 which corresponds to the decrease proportion in agricultural areas. Nevertheless the area of irrigated land increases by $4 \%$.

These changes are associated with increased regulation in the basin. In the Guadalquivir and Guadalete basins there has been a close relationship between the irrigated area and storage capacity in the basin, as well as with the change of the flow regime. Figure 5 shows as example these relationships in the Guadalete basin. A potential relationship between the irrigated area and storage capacity has been obtained for the period 1956-2007, with an $r^{2}$ of 0.92 (Fig. 5a). In the same period, the rate of flow in the channels presents a potential decrease with increasing area under irrigation, with an $r^{2}$ of 0.95 (Fig. 5b). A similar behavior has been obtained for the Guadalquivir basin, with $r^{2}$ of 0.92 for both relationships (result not shown in this paper).

\subsection{Effect of regulation on floods}

From Fig. 6a no correlation was found between the volume discharge intervals and water levels. The three highest discharge events (Fig. 6a) with a mean value of $40 \mathrm{~m}^{3} \mathrm{~s}^{-1}$ (five times over the annual mean value) corresponded to the flood events ocurred on February 2010, an extremely wet year. The annual precipitation of that year nearly doubled the annual mean.

At least on 27 occasions there was heavy rainfall and 16 floods in the study period (Fig. $6 \mathrm{~b}$ and c). Thus, some of the heavy rainfalls were attenuated by the system and did not generate significant floods in the basin. The interquartile range of the occurrence of both heavy rainfall and flood events was slightly displaced towards increasing water levels $(1-3 \mathrm{~m})$ and discharges (up to $50 \mathrm{~m}^{3} \mathrm{~s}^{-1}$ ). However, the maximum discharges $\left(>100 \mathrm{~m}^{3} \mathrm{~s}^{-1}\right)$ were found under the no- 
flood condition (Fig. 6c). Similarly, high water levels were also found for non-heavy rainfalls (Fig. 6b). Thus, a deeper analysis with longer data series needs to be carried out.

In addition, the analysis of heavy rainfall shows the necessity of: (1) a deeper climate analysis (i.e. winds directions and cut-off low phenomena), (2) a detailed study focused on the events ocurred between the upper quartile and the maximum value for the study period, and (3) more good quality rainfall data.

\section{Conclusions}

The results showed the change of the risk of flooding related to the evolution of the storage capacity in Andalusia.

As regulation increased, the level of the average flow became smaller. In this way, average discharge of Guadalquivir and Guadalete rivers to their estuaries decreased by 67 and $69 \%$, in their respective study periods. In both basins extreme values are more conditioned by the wet or dry character of the period than by the level regulation.

The comparison of natural and modified flows in the Guadalete River showed the reduction of extreme flows longer periods of medium-low flows due to the regulation effects of the reservoir. Moreover, the total annual outflow significantly decreased over the natural annual value.

Changes in land use are closely related with increasing regulation in the Guadalquivir and Guadalete basins. Thus, potential relationships between irrigated area and storage capacity and between the change of the flow regime and the storage capacity with $r^{2}>0.9$ were obtained in each basin.

In the current state of regulation of Andalusian basins, after heavy rainfalls, floods that dams are not able to retain often happen. In the Guadalhorce River some of the heavy rainfalls were attenuated by the system and did not generate significant floods in the basin. No significant correlation between discharge and floods was found. However, a deeper analysis with longer data series needs to be carried out. Nevertheless, in the Guadalhorce Basin a proper land use planning within the flooding areas may be a more effective risk reduction measure than the optimization of the hydraulic regulation structures.

In summary, regulation reduced mean flows. However, the reduction of extreme regimes was smaller since reservoir cannot store water when extreme events of precipitation happen, occurring floods even in the current situation of regulation. Land occupation of surrounding areas to rivers reduces the capacity of land to mitigate floods and increase the damage risk. In the context of the present work, human adaptation to this environment seems be more effective than the opposite in the actual situation of knowledge.

Acknowledgements. Tremendous appreciation is extended to the Spanish and Andalusian Institutions (AEMET, SAIH and Andalusian Environmental Department), that maintain and make accessible environmental datasets to scientific research.

\section{References}

Baeza Sanz, D., García de Jalón, D., Gutiérrez Teira, B., and Vizcaíno Martínez, P.: Basin influence on natural variability of rivers in semi-arid environments, Int. J. River Basin Manage., 3, 247259, 2005.

Consejería de Medio Ambiente, Junta de Andalucía: Mapa de usos y coberturas vegetales del suelo de Andalucía (MUCVA) 19561999-2003-2007, escala $1: 25$ 000, 2010.

Contreras, E.: Influence of fluvial inflows in the water quality of the Guadalquivir estuary, PhD Thesis, University of Córdoba, Spain, 2012.

Efstratiadis, A., Tegos, A., Varveris, A., and Koutsoyiannis, D.: Assessment of environmental flows under limited data availability: Case study of Acheloos River, Greece, Hydrolog. Sci. J., 59, 731-750, doi:10.1080/02626667.2013.804625, 2014.

Egüen, M.: Sources of variability in the forcing agents of the dynamics in atlantic estuaries in Andalusia (in Spanish), PhD Thesis, University of Granada, Spain, 2014.

Frazier, P. and Page, K.: The effect of river regulation on floodplain wetland inundation, Murrumbidgee River, Australia, Mar. Freshw. Res. 57, 133, 2006.

García de Jalón, D.: The Spanish experience in determining minimum flow regimes in regulated streams, Can. Water Resour. J., 28, 185-198, 2003.

Gulliver, Z., Herrero, M. J., and Polo, M. J.: Streamflow Forecasting by a Data Driven Method. Two Mediterranean study cases, International work-conference on Time series (ITISE 2014), Granada, Spain, 25-27 June 2014.

Herrero, J., Gulliver, Z., and Polo, M. J.: Flood alert system for early warning in mountainous coastal watersheds: coupling datadriven and physically based hydrological models, 11th International Conference on Hydroinformatics, New York City, USA, 2014.

Magilligan, F. J. and Nislow, K. H.: Changes in hydrologic regime by dams, Geomorphology, 71, 61-78, 2005.

Maheshwari, B. L., Walker, K. F., and McMahon, T. A.: Effects of regulation on the flow regime of the river Murray, Australia, Regul. Rivers: Res. Mgmt., 10, 15-38, 1995.

Lorenzo-Lacruz, J., Vicente-Serrano, S. M., López-Moreno, J. I., González-Hidalgo, J. C., and Morán-Tejeda, E.: The response of Iberian rivers to the North Atlantic Oscillation, Hydrol. Earth Syst. Sci., 15, 2581-2597, doi:10.5194/hess-15-25812011, 2011.

Regodón, J.: Informe sobre los episodios de mayor relevancia acaecidos en la cuenca del Guadalhorce (Málaga) por parte de la Red Hidrosur. Uso del Sistema de ayuda a la decisión (SAD) y del modelo hidrológico WiMMed. Demarcación Hidrográfica de las Cuencas Mediterráneas Andaluzas, Secretaría General del Agua. Consejería de Medio Ambiente, 2013.

Senciales, J. M. and Damián, J.: Spatial Analysis of Heavy Rain in Malaga City (Spain), Boletín de la Asociación de Geógrafos Españoles, 61, 353-360, 2013.

Wang, H., Yang, Z., Saito, Y., Liu, J., and Sun X.: Interannual and seasonal variation of the Huanghe (Yellow River) water discharge over the past 50 years: connections to impacts from ENSO events and dams, Global Planet. Change, 50, 212-225, 2006. 